\title{
Spectrophotometric Simultaneous Determination of Uranium and Thorium Using Partial Least Squares Regression and Orthogonal Signal Correction
}

\author{
Ali Niazi* \\ Department of Chemistry, Faculty of Sciences, Azad University of Arak, PO Box 38135-567, Arak, Iran
}

\begin{abstract}
Um novo método espectrofotométrico, simples e sensível, foi descrito para determinação simultânea de urânio e tório. O método é baseado na formação de complexos de urânio e tório com Arsenazo III em pH 3,0. Todos os fatores que afetam a sensibilidade foram otimizados e o intervalo dinâmico linear para determinação de cada analito foi encontrado. A determinação simultânea de urânio e tório em misturas empregando métodos espectrofotométricos é dificultada pela ocorrência de interferências espectrais. Usando métodos de calibração multivariada, tais como mínimos quadrados parciais (PLS), é possível obter um modelo ajustado aos valores das concentrações das misturas usados no intervalo de calibração. A correção do sinal ortogonal (OSC) é uma técnica de pré-processamento usada para remover informações não relacionadas às variáveis alvo, empregando análise de componentes principais restrita. OSC é um método de pré-processamento adequado para a calibração PLS de misturas, sem perda da capacidade de predição, usando-se método espectrofotométrico. Neste estudo, o modelo de calibração é baseado no espectro de absorção, no intervalo de $600-760 \mathrm{~nm}$ para 25 diferentes misturas de urânio e tório. Matrizes de calibração foram obtidas a partir de soluções contendo 0,10-21,00 e 0,2518,50 $\mu \mathrm{g} \mathrm{mL}^{-1}$ de urânio e tório, respectivamente. Os valores de RMSEP (raiz quadrada do erro médio de predição) para urânio e tório com OSC e sem OSC foram 0,4362; 0,4183 e 1,5710; 1,0775, respectivamente. Esse procedimento possibilita a determinação simultânea de urânio e tório em amostras reais e sintéticas com adequada confiabilidade na determinação.
\end{abstract}

A simple, novel and sensitive spectrophotometric method was described for simultaneous determination of uranium and thorium. The method is based on the complex formation of uranium and thorium with Arsenazo III at $\mathrm{pH}$ 3.0. All factors affecting the sensitivity were optimized and the linear dynamic range for determination of uranium and thorium found. The simultaneous determination of uranium and thorium mixtures by using spectrophotometric methods is a difficult problem, due to spectral interferences. By multivariate calibration methods such as partial least squares (PLS), it is possible to obtain a model adjusted to the concentration values of the mixtures used in the calibration range. Orthogonal signal correction (OSC) is a preprocessing technique used for removing the information unrelated to the target variables based on constrained principal component analysis. OSC is a suitable preprocessing method for PLS calibration of mixtures without loss of prediction capacity using spectrophotometric method. In this study, the calibration model is based on absorption spectra in the $600-760 \mathrm{~nm}$ range for 25 different mixtures of uranium and thorium. Calibration matrices contained 0.10 21.00 and $0.25-18.50 \mu \mathrm{g} \mathrm{mL}^{-1}$ of uranium and thorium, respectively. The RMSEP for uranium and thorium with OSC and without OSC were $0.4362,0.4183$ and $1.5710,1.0775$, respectively. This procedure allows the simultaneous determination of uranium and thorium in synthetic and real matrix samples with good reliability of the determination.

Keywords: uranium, thorium, determination, spectrophotometric, PLS, OSC

\section{Introduction}

Uranium and thorium are important elements in industry especially as energy sources. Many methods have

*e-mail: ali.niazi@gmail.com already been developed for the determination of uranium and thorium. These days, the methods include inductively coupled plasma atomic emission spectrometry (ICPAES), ${ }^{1}$ inductively coupled plasma-mass spectrometry (ICP-MS), ${ }^{2,3}$ ion chromatography (IC), ${ }^{4}$ capillary zone electrophoresis (CZE), ${ }^{5}$ and flow injection analysis (FIA) ${ }^{6}$ 
However, because these instrumental analyses require rather expensive equipment and higher running costs, they offer limited availability. Although alpha spectrometry has also been used for the determination of these radioactive elements, it needs a number of preliminary separation steps for sample preparation. ${ }^{?}$

Spectrophotometry is a relatively easy alternative method, which has been applied to determination of uranium and thorium. ${ }^{8,9}$ Most spectrophotometric methods for the determination of uranium and thorium, however, require the separation of uranium and thorium from each other in advance because the absorption maxima for uranium- and thorium-complexes are very close to each other for most chromogenic reagents. Arsenazo III is one of the most widely used chromogenic reagents because of its high sensitivity for both uranium and thorium. ${ }^{10,11}$

One of the main drawbacks of the application of spectrophotometric methods in the simultaneous determination of uranium and thorium is the high degree of spectral overlapping of these constituents. Nowadays quantitative spectrophotometry has been greatly improved by the use of a variety of multivariate statistical methods, particularly partial least squares regression (PLS). ${ }^{12}$

The basic principle of the multivariate calibration is the simultaneous utilization of many independent variables, $x_{1}, x_{2}, \ldots, x_{n}$, to quantify one or more dependent variables of interest, $y$. The partial least squares (PLS) regression analysis ${ }^{12}$ is the most widely used method for this purpose, and it is based on the latent variable decomposition relating two blocks of variables, matrices $X$ and $Y$, which may contain spectral and concentration data, respectively. These matrices can be simultaneously decomposed into a sum of $f$ latent variables, as follows:

$Y=T P^{T}+E=\Sigma t_{f} p_{f}^{\prime}+E$

$Y=U Q^{T}+F=\Sigma u_{f} q_{f}^{\prime}+F$

in which $T$ and $U$ are the score matrices for $X$ and $Y$, respectively; $P$ and $Q$ are the loadings matrices for $X$ and $Y$, respectively, $E$ and $F$ are the residual matrices. The two matrices are correlated by the scores $T$ and $U$, for each latent variable, as follows:

$u_{f}=b_{f} t_{f}$

in which $b_{f}$ is the regression coefficient for the $f$ latent variable. The matrix $Y$ can be calculated from $u_{f}$, as in equation (4), and the concentration of the new samples can be estimated from the new scores $T^{*}$, which are substituted in equation (4), leading to equation (5):

$Y=T B Q^{T}+F$

$Y_{\text {new }}=T^{*} B Q^{T}$

In this procedure, it is necessary to find the best number of latent variables, which normally is performed by using cross-validation, based on determination of minimum prediction error. ${ }^{12}$ Several determinations based on the application of this method to spectrophotometric data have been reported by several workers. ${ }^{13-21}$

Orthogonal signal correction (OSC) was introduced by Wold et al. ${ }^{22}$ to remove systematic variation from the response matrix $X$ that is unrelated, or orthogonal, to the property matrix $Y$. Therefore, one can be certain that important information regarding the analyte is retained. Since then, several group ${ }^{23-29}$ have published various OSC algorithms in an attempt to reduce model complexity by removing orthogonal components from the signal. Recently, application of orthogonal signal correction in UV-Vis spectrophotometry for simultaneous determination by partial least squares has been reported. ${ }^{30,31}$

This paper describes an analytical methodology for simultaneous determination of uranium and thorium using spectrophotometric method and a multivariate calibration technique (partial least squares) with preprocessing by orthogonal signal correction. The aim of this work is to propose orthogonal signal correction-partial least squares (OSC-PLS) method to resolve binary mixtures of uranium and thorium water samples without prior separation. The method is based on the reaction between the analytes and Arsenazo III at $\mathrm{pH}$ 3.0. The results obtained using this method are discussed.

For the evaluation of the predictive ability of a multivariate calibration model, the root mean square error of prediction (RMSEP) and relative standard error of prediction (RSEP) can be used: ${ }^{18}$

$R M S E P=\sqrt{\frac{\sum_{i=1}^{n}\left(y_{\text {pred }}-y_{\text {obs }}\right)^{2}}{n}}$

$\operatorname{RSEP}(\%)=100 \times \sqrt{\frac{\sum_{i=1}^{n}\left(y_{\text {pred }}-y_{\text {obs }}\right)^{2}}{\sum_{i=1}^{n}\left(y_{o b s}\right)^{2}}}$

where $y_{\text {pred }}$ is the predicted concentration in the sample, 
$y_{o b s}$ is the observed value of the concentration in the sample and $n$ is the number of samples in the validation set.

\section{Experimental}

\section{Reagents}

Arsenazo III, acetic acid, phosphoric acid, boric acid, hydrochloric acid, sodium hydroxide, uranyl nitrate hexahydrate and thorium nitrate hexahydrate were purchased from Merck. All reagents used were of analytical reagent grade. Standard stock solutions of $1000 \mu \mathrm{g} \mathrm{mL}^{-1}$ thorium (IV) and uranium (VI) were prepared by dissolving appropriate amounts of thorium nitrate and uranyl nitrate hexahydrate in water, respectively. Analytical working solutions were made daily by appropriate dilution as required. A stock Arsenazo III solution $\left(1.0 \times 10^{-4} \mathrm{mmol} \mathrm{mL}^{-1}\right)$ was prepared by dissolving reagent. A universal buffer solution $(\mathrm{pH}$ 3.0) was prepared according to Lurie. ${ }^{32}$ All the solutions were prepared in deionized water.

\section{Apparatus and software}

A Perkin Elmer (Lambda 25) spectrophotometer controlled by a computer and equipped with a $1 \mathrm{~cm}$ path length quartz cell was used for UV-Vis spectra acquisition. Spectra were acquired between 600 and 760 $\mathrm{nm}$ (1 nm resolution). A HORIBA M-12 pH-meter furnished with a combined glass-saturated calomel electrode was calibrated with at least two buffer solutions at $\mathrm{pH} 3.0$ and 9.0.

The data were treated in an AMD 2000 XP $(256 \mathrm{Mb}$ RAM) microcomputer using MATLAB software, version 6.5 (The MathWorks). OSC and PLS calculations were carried out in the 'PLS Toolbox', version 2.0 (Eigenvector Technologies).

\section{Procedure}

Known amounts of the standard solutions were placed in a $10 \mathrm{~mL}$ volumetric flask and completed to the final volume with deionized water (final $\mathrm{pH}$ 3.0). The final concentrations of these solutions varied between 0.1021.00 and $0.25-18.50 \mu \mathrm{g} \mathrm{mL}^{-1}$ for uranium and thorium, respectively.

\section{Real samples}

The real samples in this study were collected in waters from spring and river. The particulates of collected water were first removed by filter paper. The range of concentrations uranium and thorium were added to be $0.10-21.00$ and $0.25-18.50 \mu \mathrm{g} \mathrm{mL}^{-1}$, respectively.

\section{Results and Discussion}

\section{Spectrophotometric measurements}

Figure 1 shows the absorption spectra in aqueous solution of the individual uranium and thorium complexes and Arsenazo III at $\mathrm{pH}$ 3.0. As this figure shows, there is a clear overlapping of the two spectra. This prevents the simultaneous determination of the uranium and thorium by direct UV-Vis absorbance measurements. To overcome this problem a suitable and simple technique, which presents a good recovery, is PLS regression. Spectra of mixtures of uranium and thorium solutions between 600 and $760 \mathrm{~nm}$ wavelengths by $1 \mathrm{~nm}$ intervals were recorded, and then the data were digitized and stored for late treatment.

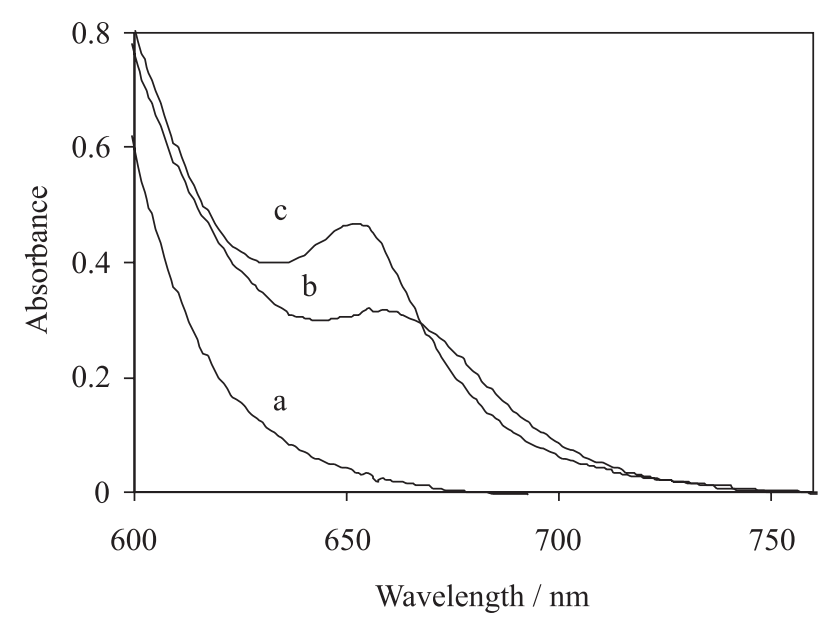

Figure 1. Absorption spectra of (a) $8.5 \times 10^{-5} \mathrm{mmol} \mathrm{mL}^{-1}$ of Arsenazo III, (b) $5 \mu \mathrm{g} \mathrm{mL}-1$ of uranium and (c) $5 \mu \mathrm{g} \mathrm{mL} \mathrm{m}^{-1}$ of thorium with $8.5 \times 10^{-5}$ $\mathrm{mmol} \mathrm{mL} \mathrm{m}^{-1}$ of Arsenazo III at $\mathrm{pH} 3.0$.

\section{Optimization of experimental condition}

For finding the optimum conditions, the influence of $\mathrm{pH}$ values on the spectrum of each complex at a constant concentration of each ion was studied. The formed complexes with uranium and thorium were affected differently with $\mathrm{pH}$. In order to select the optimum $\mathrm{pH}$ value at which the minimum overlap occurs, influences of the $\mathrm{pH}$ of the medium on the absorption spectra of uranium and thorium complexes were studied over the $\mathrm{pH}$ range 1.0-8.0. However $\mathrm{pH}$ 3.0 was chosen as the optimum $\mathrm{pH}$ for this work because both complexes have maximum absorbance and minimum overlap at this $\mathrm{pH}$. 
Effect of the concentration of the Arsenazo III was also investigated, a reagent concentration of $8.5 \times 10^{-5}$ $\mathrm{mmol} \mathrm{mL} \mathrm{m}^{-1}$ was chosen because it ensures sufficient reagent excess. Individual calibration curves were constructed with several points as absorbance versus metals concentration. For constructing the individual calibration lines the absorbancies were measured at 662 and $656 \mathrm{~nm}$ against a blank for uranium and thorium, respectively. The linear regression equation for the calibration graph for uranium for the concentration range of $0.10-21.00 \mu \mathrm{g} \mathrm{mL}^{-1}$ was $\mathrm{A}=0.0752+0.0567 \mathrm{C}_{\text {uranium }}$ $\left(r^{2}=0.9987, n=17\right)$ and for thorium for the concentration range of $0.25-18.50 \mu \mathrm{g} \mathrm{mL}^{-1}$ was $\mathrm{A}=0.1781+0.0596 \mathrm{C}_{\text {thrium }}$ $\left(r^{2}=0.9988, n=15\right)$. The limits of detection were 0.07 and $0.13 \mu \mathrm{g} \mathrm{mL}^{-1}$ for uranium and thorium, respectively, were calculated according to calibration line characteristic.

\section{Calibration and prediction data sets}

The multivariate calibration is a powerful tool for determinations, because it extracts more information from the data and allows building more robust models. According to 25 experimental design (Table 1) solutions were used to construct the models (calibration set) and another 10 solutions to validate them (prediction set) in that these were not included in the calibration set but were employed for independent tests (see Table 2). All recorded data are mean-centered..$^{33}$

The calibration matrix was experimentally designed over the concentration ranges of $0.10-21.00$ and 0.25 $18.50 \mathrm{mg} \mathrm{mL}^{-1}$ for uranium and thorium, respectively. According to the following basic rules. First, the calibration standards should be mixtures of components in order to compensate for effects on absorbance from interaction between the components. Second, the peak absorbance of each standard should be lower than 2.5 in the analytical wavelength range. Finally, the concentration of all of the components must be independently varied within the set of standards. To ensure that the prediction and real samples are in the subspace of the training set, the score plot of first principal component versus second was sketched and all the samples are spanned with the training set scores.

\section{Preprocessing by orthogonal signal correction}

For calibration set two OSC components were used for filtering. Evaluation of the prediction errors for the validation set reveals that the OSC treated data give substantially lower RMSEP values than original data. Also, the OSC-filtered data give much simpler calibration models with fewer components than the ones

Table 1. Concentration data of the different mixtures used in the calibration set for the determination of thorium and uranium $\left(\mu \mathrm{g} \mathrm{mL}^{-1}\right)$

\begin{tabular}{lcccccccc}
\hline Mixture & Thorium & Uranium & Mixture & Thorium & Uranium & Mixture & Thorium & Uranium \\
\hline M1 & 0.25 & 0.10 & M10 & 4.40 & 21.00 & M19 & 13.80 & 15.70 \\
M2 & 0.25 & 5.20 & M11 & 9.10 & 0.10 & M20 & 13.80 & 21.00 \\
M3 & 0.25 & 10.50 & M12 & 9.10 & 5.20 & M21 & 18.50 & 0.10 \\
M4 & 0.25 & 15.70 & M13 & 9.10 & 10.50 & M22 & 18.50 & 5.20 \\
M5 & 0.25 & 21.00 & M14 & 9.10 & 15.70 & M23 & 18.50 & 10.50 \\
M6 & 4.40 & 0.10 & M15 & 9.10 & 21.00 & M24 & 18.50 & 21.00 \\
M7 & 4.40 & 5.20 & M16 & 13.80 & 0.10 & M25 & \\
M8 & 4.40 & 10.50 & M17 & 13.80 & 5.20 & & & \\
M9 & 4.40 & 15.70 & M18 & 13.80 & 10.50 & & \\
\hline
\end{tabular}

Table 2. Added and determined results of synthetic mixtures of thorium and uranium $\left(\mu \mathrm{g} \mathrm{mL}^{-1}\right)$

\begin{tabular}{|c|c|c|c|c|c|c|c|c|c|}
\hline \multirow{2}{*}{$\begin{array}{l}\text { Added } \\
\text { Thorium }\end{array}$} & \multirow[b]{2}{*}{ Uranium } & \multicolumn{2}{|c|}{ Determined (PLS) } & \multicolumn{2}{|c|}{ Recovery / (\%) } & \multicolumn{2}{|c|}{ Determined (OSC-PLS) } & \multicolumn{2}{|c|}{ Recovery / (\%) } \\
\hline & & Thorium & Uranium & Thorium & Uranium & Thorium & Uranium & Thorium & Uranium \\
\hline 0.75 & 0.65 & 0.88 & 0.59 & 117.3 & 90.77 & 0.85 & 0.62 & 113.3 & 95.38 \\
\hline 3.00 & 3.50 & 2.63 & 4.12 & 87.67 & 117.7 & 2.75 & 3.81 & 91.67 & 108.9 \\
\hline 10.00 & 3.50 & 11.56 & 3.11 & 115.6 & 88.86 & 9.60 & 3.63 & 96.00 & 103.7 \\
\hline 18.00 & 11.00 & 16.95 & 9.33 & 94.17 & 84.82 & 18.57 & 10.67 & 103.2 & 97.00 \\
\hline 5.00 & 15.00 & 5.37 & 12.35 & 107.4 & 82.36 & 5.06 & 14.08 & 101.2 & 93.87 \\
\hline 5.00 & 20.00 & 5.51 & 22.85 & 110.2 & 114.3 & 5.00 & 20.50 & 100.0 & 102.5 \\
\hline 19.00 & 15.00 & 17.65 & 16.33 & 92.89 & 108.9 & 18.34 & 15.29 & 96.53 & 101.9 \\
\hline 10.00 & 10.00 & 11.30 & 9.23 & 113.0 & 92.30 & 10.51 & 9.41 & 105.1 & 94.10 \\
\hline 18.00 & 15.00 & 16.88 & 15.86 & 93.78 & 105.7 & 17.79 & 15.34 & 98.83 & 102.3 \\
\hline 13.00 & 18.00 & 14.66 & 16.23 & 112.8 & 90.17 & 13.67 & 18.19 & 105.2 & 101.1 \\
\hline
\end{tabular}


(a)

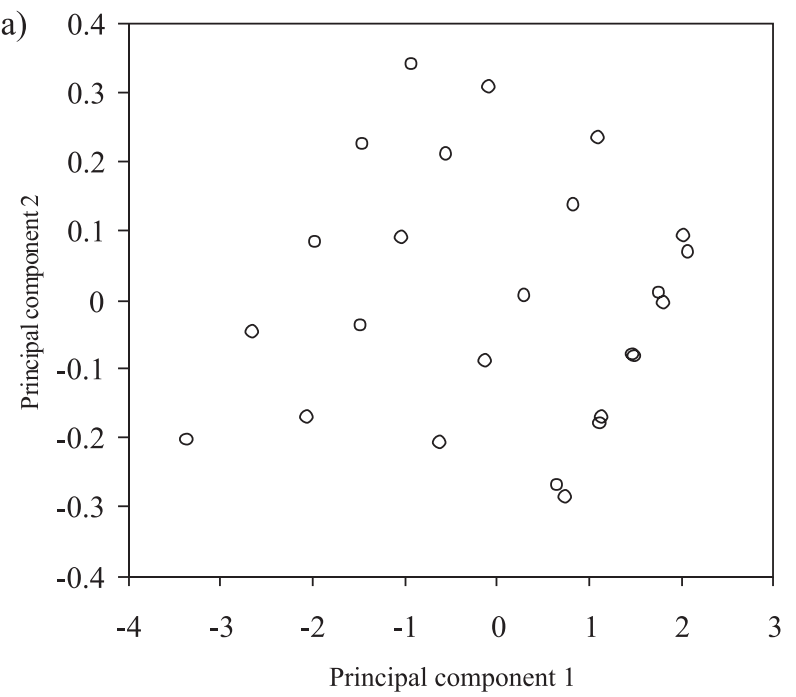

(b)

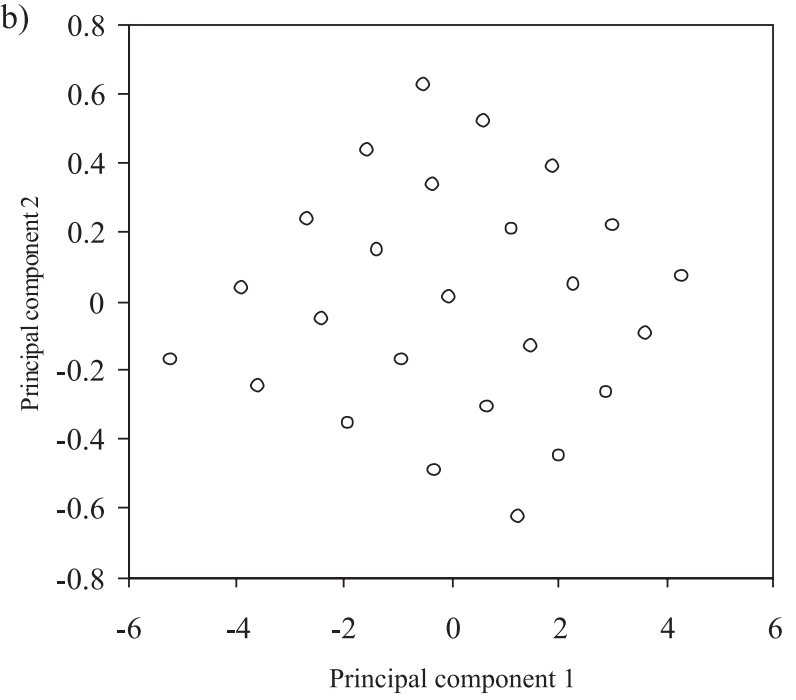

Figure 2. Plots of first principal component against second principal component for uranium and thorium determination (a) by PLS model, (b) by OSC-PLS model.

based on original data. The results imply that the OSC method indeed removes information from UV-Visible data that is not necessary for fitting of the $\mathrm{Y}$ variables. In some cases the OSC method also removes non-linear relationships between $\mathrm{X}$ and $\mathrm{Y}$. Figure 2 shows the score plot for when the PLS and OSC-PLS are used. The score plots are shown for comparison of the results obtained from PLS and OSC-PLS. The results show, score plots have better results when OSC-PLS is used. Score plots reveal the geometrical placement of the solutions in principal components space. The experimental noise can destroy this relation but by removing the noise using OSC filtering, the OSC-PLS score plots (Figure 2b) depict in a more clear way.
Selection of the optimum number of factors

The optimum number of factors (latent variables) to be included in the calibration model was determined by computing the prediction error sum of squares (PRESS) for cross-validated models using a high number of factors (half the number of total standard +1 ), which is defined as follows:

PRESS $=\sum_{i=1}^{n}\left(y_{i}-\hat{y}_{i}\right)^{2}$

where $y_{i}$ is the reference concentration for the $i$ th sample and $\hat{y}_{i}$ represents the estimated concentration. The crossvalidation method employed was to eliminate only one sample at a time and then PLS calibrate the remaining standard spectra. By using this calibration the concentration of the sample left out was predicted. This process was repeated until each standard had been left out once.

One reasonable choice for the optimum number of factors would be that number which yielded the minimum PRESS. Since there are a finite number of samples in the training set, in many cases the minimum PRESS value causes overfitting for unknown samples that were not included in the model. A solution to this problem has been suggested by Haaland and Thomas $^{34,35}$ in which the PRESS values for all previous factors are compared to the PRESS value at the minimum. The Fstatistical test can be used to determine the significance of PRESS values greater than the minimum.

The maximum number of factors used to calculate the optimum PRESS was selected as 13 and the optimum number of factors obtained by the application of PLS and OSC-PLS models are summarized in Table 3. In all instances, the number of factors for the first PRESS values whose F-ratio probability drops below 0.75 was selected as the optimum. In Figure 3, the PRESS obtained by optimizing the calibration matrix of the absorbance data with PLS and OSC-PLS models is shown.

Table 3. Statistical parameters of the optimized matrix using the OSCPLS and PLS

\begin{tabular}{lcccc}
\hline & NPC & PRESS & RMSEP & RSEP / (\%) \\
\hline Thorium $^{\mathrm{b}}$ & 4 & 0.1110 & 0.4183 & 3.489 \\
Uranium $^{\mathrm{b}}$ & 4 & 0.1346 & 0.4362 & 3.401 \\
Thorium $^{\mathrm{c}}$ & 10 & 0.5203 & 1.078 & 8.986 \\
Uranium $^{\mathrm{c}}$ & 7 & 0.3416 & 1.571 & 12.25 \\
\hline
\end{tabular}

${ }^{a}$ Number of principal component. ${ }^{b}$ Using OSC-PLS. ${ }^{c}$ Using PLS.

Determination of uranium and thorium in synthetic mixtures

The predictive ability of method was determined using 10 two-component uranium and thorium mixtures (their 


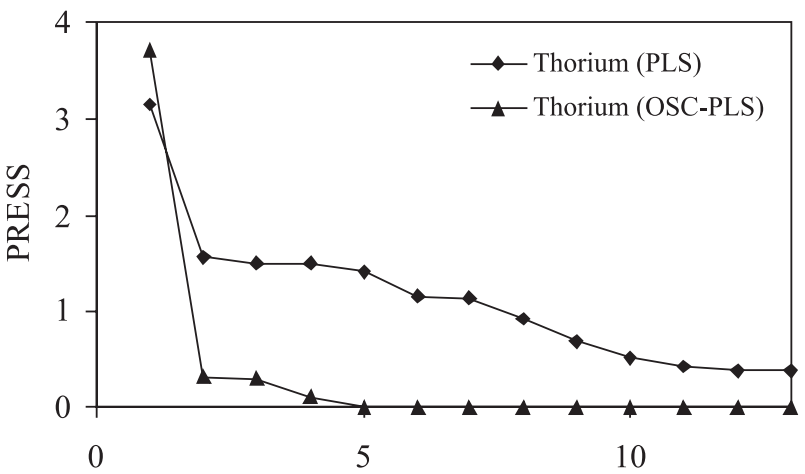

Number of Factors

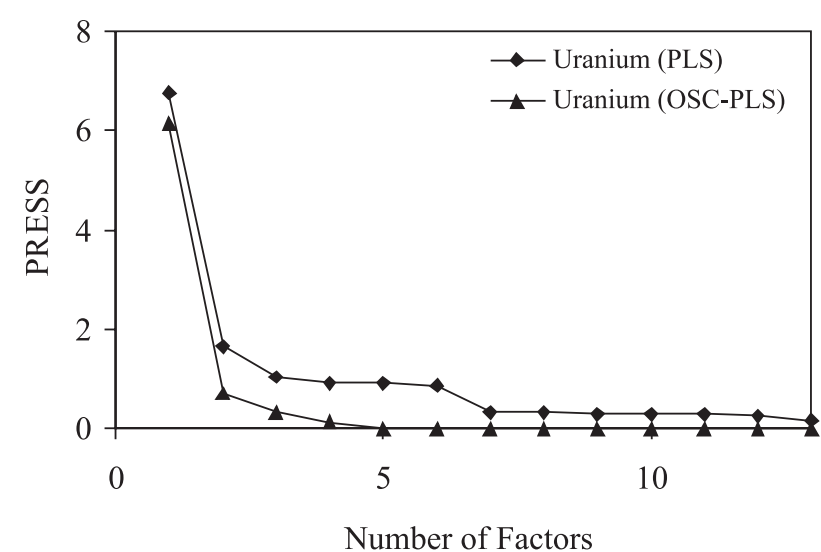

Figure 3. Plots of PRESS versus number of factors by PLS and OSCPLS.

compositions are given in Table 2). The results obtained by applying PLS and OSC-PLS algorithm to ten synthetic samples are listed in Table 2. Table 2 also shows the recovery for the prediction set of uranium and thorium mixtures. As it can be seen, the percentage error was also quite acceptable. The average recovery for thorium and uranium with OSC and without OSC were 101.1, 100.1\% and $104.5,97.6 \%$, respectively. The root mean square error of prediction (RMSEP) and relative standard error of prediction (RSEP) results summarized in Table 3. The plots of the predicted concentration versus actual values are shown in Figure 4 for uranium and thorium (line equations and $\mathrm{R}^{2}$ values are also shown).

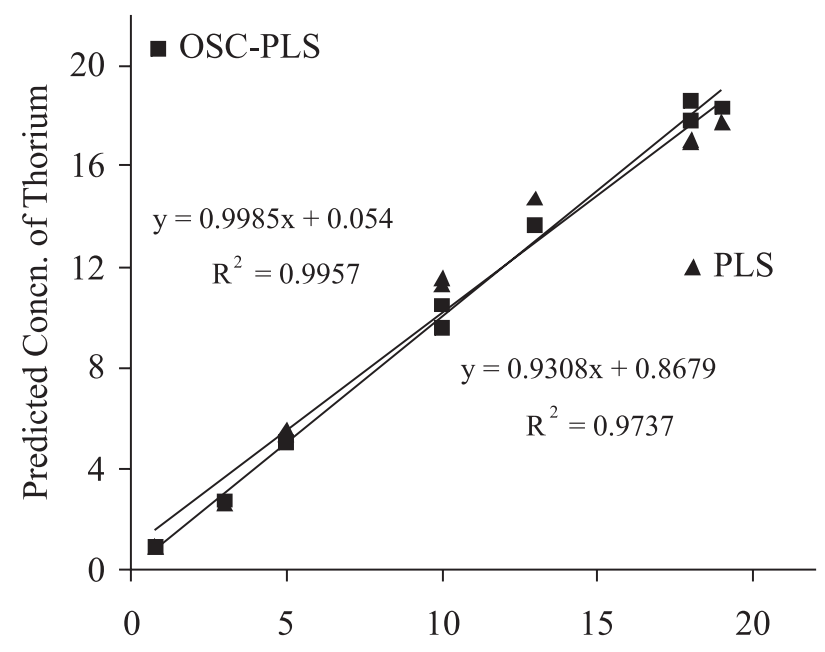

Actual Concn. of Thorium

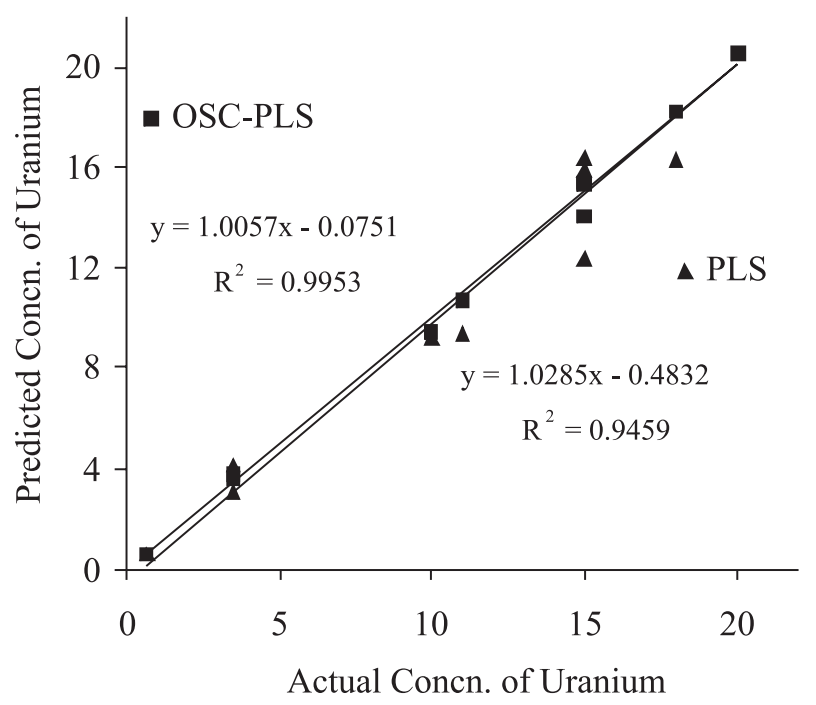

Figure 4. Plots of predicted concentration versus actual concentration for uranium and thorium by PLS and OSC-PLS $\left(\mu \mathrm{gL}^{-1}\right)$.

\section{Determination of uranium and thorium in real matrix} samples

In order to test the applicability and matrix interferences of the proposed method to the analysis of real samples, the method was applied in a variety of situations. For this purpose, diverse spiked samples and

Table 4. OSC-PLS results applied on the real matrix samples $\left(\mu \mathrm{g} \mathrm{mL}^{-1}\right)$

\begin{tabular}{|c|c|c|c|c|c|c|c|c|}
\hline \multirow[t]{2}{*}{ Type of water } & \multicolumn{4}{|c|}{ Thorium } & \multicolumn{4}{|c|}{ Uranium } \\
\hline & Added & Determined & S.D. ${ }^{a}$ & Recovery / (\%) & Added & Determined & S.D. ${ }^{a}$ & Recovery / (\%) \\
\hline Spring water & 0.50 & 0.46 & 3.68 & 92.0 & 1.60 & 1.52 & 2.97 & 95.0 \\
\hline Spring water & 5.00 & 4.86 & 2.03 & 97.2 & 4.50 & 5.10 & 2.12 & 113.0 \\
\hline River water & 8.00 & 8.21 & 1.56 & 102.6 & 8.00 & 7.88 & 1.66 & 98.5 \\
\hline River water & 4.50 & 4.69 & 2.38 & 104.2 & 11.00 & 11.21 & 1.43 & 101.9 \\
\hline River water & 12.00 & 12.68 & 1.62 & 105.7 & 4.00 & 4.32 & 1.73 & 108.0 \\
\hline
\end{tabular}

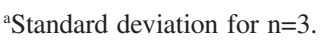


reference materials were analyzed. Table 4 shows the results obtained for real matrix samples. Therefore, the OSC-PLS model is able to predict the concentrations of each uranium and thorium in the real matrix sample.

\section{Conclusions}

The uranium and thorium mixture is a complex system due to its high spectral overlapping between the absorption spectra of their individual component. However, a simple, easy and inexpensive method such as PLS in a very short time was applied to overcome this problem. In addition, the present study shows that the OSC can be a good method for removing systematic variation from the response matrix $X$ that is unrelated, or orthogonal, to the property matrix Y. Therefore, one can be certain that important information regarding the analyte is retained. The good agreement clearly demonstrates the utility of this procedure for the simultaneous determination of uranium and thorium mixtures without tedious pretreatment in complex samples in synthetic and water samples.

\section{References}

1. Fujino, O.; Umetani, S.; Ueno, E.; Shigeta, K.; Mastsuda, T.; Anal. Chim. Acta 2000, 420, 65.

2. Sen Gupta, J. G.; Bertrand, N. B.; Talanta 1995, 42, 1595.

3. Joannon, S.; Telouk, P.; Pin, C.; Spectrochim. Acta, Part B 1997, 52, 1783 .

4. Borai, E. H.; Mady A. S.; Appl. Radiat. Isot. 2002, 57, 463.

5. Liu, B.; Liu, L.; Cheng, J.; Talanta 1998, 47, 291.

6. Hirano, Y.; Ogawa, Y.; Oguma, K.; Anal. Sci. 2003, 19, 303.

7. Tome, F. V.; Blanco Rodriguez, M. P.; Lozano, J. C.; Appl. Radiat. Isot. 2001, 56, 393.

8. Marczenko, Z.; Separation and Spectrophotometric Determination of Elements, Ellis Horwood: Chichester, 1986.

9. Onishi H.; Photometric Determination of Traces of Metals, Part IIB, John Wiley: New York, 1989.

10. Amin, A. S.; Mohammed, T. Y.; Talanta 2001, 54, 611.
11. Kuroda, R.; Kurosaki, M.; Hayashibe, Y.; Ishimuru, S.; Talanta 1990, 37, 619 .

12. Martens, H.; Naes, T.; Multivariate Calibration, John Wiley: Chichester, 1989.

13. Ghasemi, J.; Niazi, A.; Microchem. J. 2001, 68, 1.

14. Ghasemi, J.; Niazi, A.; Safavi, A.; Anal. Lett. 2001, 34, 1389.

15. Ghasemi, J.; Amini, R.; Niazi, A.; Anal. Lett. 2002, 35, 533.

16. Ghasemi, J.; Niazi, A.; Leardi, R.; Talanta 2003, 59, 311.

17. Ghasemi, J.; Niazi, A.; Ghobadi, S.; J. Chin. Chem. Soc. 2005, $52,1049$.

18. Ghasemi, J.; Niazi, A.; Anal. Chim. Acta 2005, 533, 169.

19. Niazi, A.; Ghasemi, J.; Yazdanipour, A.; Anal. Lett. 2005, 38, 2377.

20. Ghasemi, J.; Ebrahimi, D. M.; Hejazi, L.; Leardi, R.; Niazi, A.; J. Anal. Chem. 2006, 61, 92.

21. Niazi, A.; Sadeghi, M.; Chem. Pharm. Bull. 2006, 54, 711.

22. Wold, S.; Antii, H.; Lindgren, F.; Ohman, J.; Chemom. Intell. Lab. Syst. 1998, 44, 175.

23. Sjoblom, J.; Svensson, O.; Josefson, M.; Kullberg, H.; Wold, S.; Chemom. Intell. Lab. Syst. 1998, 44, 229.

24. Andersson, C. A.; Chemom. Intell. Lab. Syst. 1999, 47, 51.

25. Wise, B. M.; Gallagher, N.B.; http://www.eigenvector.com/ MATLAB/OSC.html

26. Fearn, T.; Chemom. Intell. Lab. Syst. 2000, 50, 47.

27. Pierna, J. A. F.; Massart, D. L.; Noord, O. E.; Ricoux, P.; Chemom. Intell. Lab. Syst. 2001, 55, 101.

28. Westerhuis, J. A.; Jong, S.; Smilde, A. K.; Chemom. Intell. Lab. Syst. 2001, 56, 13.

29. Wold, S.; Trygg, J.; Berglund, A.; Antii, H.; Chemom. Intell. Lab. Syst. 2001, 58, 131.

30. Ghasemi, J.; Saaidpour, S.; Ensafi, A. A.; Anal. Chim. Acta 2004, 508, 119.

31. Ghasemi, J.; Niazi, A.; Talanta 2005, 65, 1168.

32. Lurie, J. J.; Handbook of Analytical Chemistry, Mir publication: Moscow, 1978.

33. Geladi, P.; Kowalski, B. R.; Anal. Chim. Acta 1986, 185, 1.

34. Haaland, D. M.; Thomas, E. V.; Anal. Chem. 1988, 60, 1193.

35. Haaland, D. M.; Thomas, E. V.; Anal. Chem. 1988, 60, 1202.

Received: April 5, 2006

Published on the web: July 13, 2006 